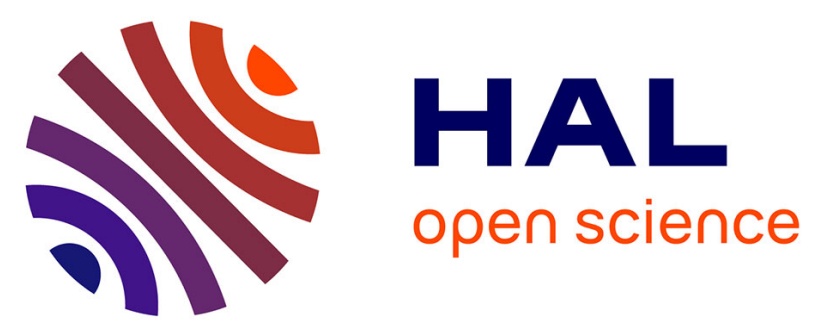

\title{
Systems Thinking in Risk Management by Preventive \& Detective Controls as an Ago-Antagonistic Systems Approach in the French Nuclear Sector
}

Diana Paola Moreno Alarcon, Jean François Vautier, Guillaume Hernandez, Franck Guarnieri

\section{To cite this version:}

Diana Paola Moreno Alarcon, Jean François Vautier, Guillaume Hernandez, Franck Guarnieri. Systems Thinking in Risk Management by Preventive \& Detective Controls as an Ago-Antagonistic Systems Approach in the French Nuclear Sector. 29th European Safety and Reliability Conference (ESREL2019), Sep 2019, Hannover, Germany. 10.3850/978-981-11-2724-3_0243-cd . hal-02308657v1

\section{HAL Id: hal-02308657 \\ https://hal.science/hal-02308657v1}

Submitted on 8 Oct 2019 (v1), last revised 10 Oct 2019 (v2)

HAL is a multi-disciplinary open access archive for the deposit and dissemination of scientific research documents, whether they are published or not. The documents may come from teaching and research institutions in France or abroad, or from public or private research centers.
L'archive ouverte pluridisciplinaire HAL, est destinée au dépôt et à la diffusion de documents scientifiques de niveau recherche, publiés ou non, émanant des établissements d'enseignement et de recherche français ou étrangers, des laboratoires publics ou privés. 


\author{
Diana Paola MORENO ALARCON \\ CRC, MINES ParisTech, PSL-Research University,France.E-mail: diana.moreno@mines-paristech.fr
}

Jean François VAUTIER

CEA (French Atomic Energy \& Alternative Energies Commission), France.E-mail:jean-francois.vautier@cea.fr

Guillaume HERNANDEZ

CEA (French Atomic Energy \& Alternative Energies Commission),France.E-mail: guillaume.hernandez@cea.fr

Franck GUARNIERI

CRC, MINES ParisTech, PSL-Research University,France.E-mail: franck.guarnieri@mines-paristech.fr

The French Atomic Energy and Alternative Energies Commission (CEA) employ preventive and detective controls, fundamental elements of risk management in the nuclear facilities of the French nuclear sector. Using an ago-antagonistic systems (AAS) approach, CEA managers balance two ago-antagonistic (AA) forces (preventive and detective controls) that together make an AA couple, to mitigate subcontracting risks. The systemic vision of AAS, underpinned by systems thinking, enables managers to consider the collective impact of adjusting either a single force or both forces, particularly as action(s) on the couple may rebalance the overall system. This paper illustrates how preventive and detective controls meet Bernard-Weil's eight principal characteristics of AAS. The temporal aspect of preventive and detective controls, at the nucleus of the AA model, and their time-sensitive role in averting and detecting an event are also discussed. Examples are provided of how CEA managers mitigate risk through AA couples by pursuing forces and considering them collectively in terms of "both /and" rather than separately in terms of "either/or".

Keywords: Ago-antagonistic Systems (AAS), Risk Management, Preventive Controls, Detective Controls, Management Controls, Subcontracting, Nuclear Sector, Systems Thinking, Defence in Depth, Temporal aspects

\section{Introduction}

Over the past 50 years, the concept of defence in depth has been imperative in nuclear safety and has influenced the design and operation of nuclear facilities, thereby providing an approach to both prevent postulated accidents and mitigate their consequences (INSAG, 1996, 1999). Specifically, this approach enforces the creation of multiple independent barriers or echelons of protection to compensate for potential human and organizational failures, so not to rely on a single level of defence irrespective of its robustness. France's Decree from February 7, 2012, the general rules for nuclear facilities, details the safety framework to be respected by nuclear operators. It promotes the 5 levels of defence in depth through the use of access controls, physical barriers, redundant and diverse key safety functions, and emergency response measures. This paper focuses on the first two levels of defence in depth: Level $\mathbf{1}$ addresses the prevention of incidents and of abnormal operations (hereafter referred to as $L 1$ preventive control), while Level 2 focuses on the detection of incidents and failures (hereafter referred to as L2 detective control).

This paper proposes the use of an Agoantagonistic Systems (AAS) approach to analyze and balance $L 1$ preventive and $L 2$ detective controls used by the French Alternative Energies and Atomic Energy Commission (CEA) in the prevention and mitigation of three subcontracting risks: (1) the non-application of the normative framework (relational risk), (2) failure to obtain expected results (performance risk) which may lead to (3) a non-compliance of regulations yielding adversity with external authorities (compliance and regulatory risk) (Anderson et al., 2014; Das \& Teng, 2000, 2001). Such risks are exacerbated by the organizational distance between two entities of the contractor-subcontractor relationship, an interaction that represents a mere fraction of the risk management system. Our results come from two nuclear facilities at the CEA.

Scholars (Arnold \& Wade, 2015; Tosello, et al., 2012; Vautier et al., 2018a) have proposed

\title{
Proceedings of the 29th European Safety and Reliability Conference.
}

Edited by Michael Beer and Enrico Zio

Copyright (c) 2019 European Safety and Reliability Association.

Published by Research Publishing, Singapore.

ISBN: 978-981-11-2724-3; doi:10.3850/978-981-11-2724-3_0243-cd 
the use of systemic tools to allow managers to see the system holistically, taking into account the dynamics of the system by focusing on dialogical couples and their effects. The AAS approach, underpinned by systems thinking, combines concepts that have both antagonistic (opposite) and agonistic (parallel positive) effects on the system (Bernard-Weil, 2002; 2003). One such ago-antagonistic (AA) couple includes the managerial tools of preventive and detective nature used in risk management at the CEA. The contractor employs detective controls to ensure subcontractors use adequate rules, policies, and procedures (normative guidelines) and also supervises behaviors and results in order to maximize performance (Anderson et al., 2014; Das \& Teng, 2000, 2001; Eisenhardt, 1985; Merchant, 1985; Ouchi, 1979). Additionally, preventive controls promote shared social values, beliefs, and goals by reinforcing and rewarding appropriate behaviors amongst members of the two firms, thereby averting potential events of the multiple actor interactions within the system (Das \& Teng, 2001; Vautier et al., 2018a).

The following section introduces the research constructs surrounding AAS (systems thinking, AAS model, and characteristics of AAS). The next section details the implication of these AAS on managerial controls (preventive and detective controls, and temporal aspect of averting an unwanted event). Finally, empirical references of AA couples at the CEA are provided.

\section{Constructs of Ago-antagonistic Systems}

\subsection{Systems Thinking}

A system is a global unit made up of a "set of elements which interact together in a dynamic manner and are organized to achieve a specific goal" (De Rosnay, 1975, 2014).

Systems thinking is a set of synergistic analytic skills used to improve the capability of identifying and understanding systems, predicting their behaviors, and devising modifications to them in order to produce desired effects (Arnold \& Wade, 2015). These skills work together and are "methodological supports that link knowledge, expertise, and data from various disciplines relating to the same system" (Garbolino et al., 2019). By connecting the units of a system, systems thinking provides a holistic vision that unifies a group of variables and sheds clarity on the effect of their interactions (De Rosnay, 1975, 2014). The resultant global template permits elements of the system to be acted upon either directly or indirectly by changing a parameter in parallel to the element.

Durand (2006) characterizes the systemic approach by four characteristics:

- Elements within a system must interact with each other, performing actions on certain elements while being subjected to actions from other elements. Elements that do not interact are external to the system (Garbolino et al., 2019).

- Elements have irreducible properties (cannot be reduced to the sum of their parts) that transform depending on the degree of agreeability between these elements and on their hierarchy within the system (Garbolino et al., 2019). Durand, (2006) referred to this as comprehensiveness.

- The organization of the system takes into account the structure of the system and its operations in attaining a common goal.

- The system's complexity can be witnessed by its sensitivity to changes in conditions and by its adaptability constraints (Garbolino et al., 2019). This complexity impedes the ability to predict the dynamics and evolution of the system (Donnadieu \& Karsky, 2002).

These four characteristics of the systemic approach highlight the importance of using systemic modeling tools such as an AAS in risk management; particularly as traditional causal analysis tools model events and causal factors linearly. As a result, such traditional tools are not designed to analyze complex interactions between actors, the temporal and spatial gaps between these actors or their consequences (Goh et al., 2010). Given the importance of the interactions between actors (subcontractorcontractor) and the temporal aspects of $L 1$ preventive and $L 2$ detective controls, a systems thinking approach is extremely pertinent.

\subsection{Ago-antagonistic Systems Model}

The French endocrinologist E. Bernard-Weil formalized AAS during his work on adrenalpost-pituitary interactions and later applied this model to successfully solve other endocrine disorders (Nunez, 1997). To date, this model proposes a more abstract and theoretical application to numerous scientific fields (Bernard-Weil et al., 1975; Corbel et al., 2007; Martinet \& Payaud, 2006; Zouaghi \& Spalanzani, 2009). The term "ago-antagonistic" (AA) is composed of two terms: antagonistic meaning "opposite effects"; and agonistic meaning "parallel positive effects" (BernardWeil, 2002; 2003). The AA approach consists of 
analyzing couples whose forces have both "opposite, antagonistic effects on certain receivers of these actions" and "parallel positive, agonistic effects on other parts of the same receiver", thereby "taking into account the unity to which both sides belong" (BernardWeil, 2002; 2003).

Our AA model, illustrated in Figure 1, contains four components: two forces ( $x$ - preventive controls, $y$-detection controls), a regulator (CEA) and a receiver (subcontracting risks). This systemic vision enables the regulator to consider the collective impact of adjusting either a single force ( $x$ or $y$ ) or both forces ( $x$ and $y)$, particularly as action(s) on the couple may rebalance the overall system (Bernard-Weil, 1999, 2003).

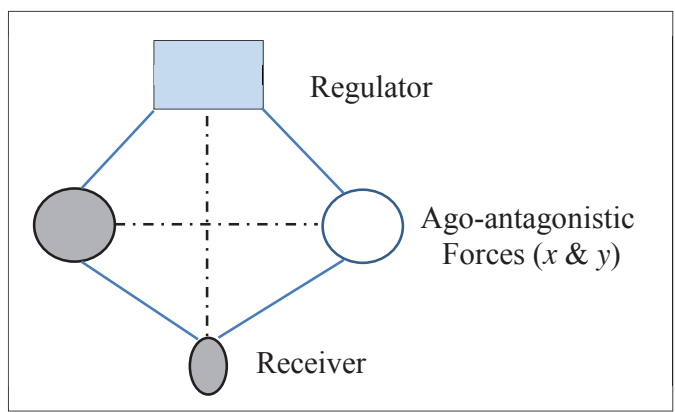

Fig. 1. Ago-antagonistic Model of risk management at the CEA.

\subsection{Characteristics of Ago-antagonistic Systems}

AAS can be identified by eight (8) principal characteristics (Bernard-Weil, 1975; 1999; 2003; Zouaghi \& Spalanzani, 2009): The first defines an AA couple, whose poles have opposing actions on one part of the receiver and actions in the same direction on another part of the receiver (see Figure 1). The second denotes AAS as a dissipative system, a thermodynamically open system defined by Nobel Lauriat Prigogine, which describes equilibrium against a standard or a reproducible ready state. Mathematically AAS has two equilibrium states: a physiological equilibrium (if the standards are respected) and a pathological equilibrium (run on poor standards). As a result, equilibrium will oscillate around the equilibrium point known as equilibrium constant. The third describes an AA network made up of a combination of AA elementary couples. This network is organized into competing pressures of hierarchy and autonomy, explaining how an action on one part of the network can rebalance the entire network. The fourth is the concept of constituent division whereby one force acts in its own interest and simultaneously for the common interest of the system. The fifth explains that AAS integrates dichotomies, a series of properties typically opposing compatibility with each other (external-internal; dangers-safety; contractor-subcontractor). The sixth proposes that AAS have states comparable to pathological homeostasis or autonomy, thereby resulting in unusual strategies within these complex systems. The seventh highlights false AA couples such as imbalance and balance, good and evil, which are not AA despite their semantic opposition. The eighth characteristic indicates that all models irrespective of their "universality" require a meta-model. However, the meta-model of the AA model is yet to be created or identified.

\section{Implications of Ago-antagonistic Systems on managerial controls}

\subsection{Preventive and detective controls}

Controls are tools that avert and mitigate errors and anomalies. When used correctly, L1 preventive controls are very effective as they anticipate and preclude undesirable behaviors. These behaviors can also be identified and corrected (but not averted) by L2 detective controls. The sequential presence of $L 1$ preventive and $L 2$ detective controls is dependent on numerous parameters described below (see Table 1).

L1 Preventive controls minimize goal discrepancies between the receptor (subcontractor) and the regulator (contractor) by establishing common culture and values. They can be defined as a task that aims to ensure the performance of the operating process. This task may not result in action directly influencing the process and are performed by actors who are part of the operating process. These actors, such as the facility chief or safety officer, are stakeholders in the operating process and are entrusted with responsibilities. $L 1$ preventive controls take place before and during the task. A directory of verbs used to describe $L 1$ preventive controls includes: to ensure, to follow, to organize, to dispense, to review, to program, and to authorize. 
L2 detective controls enforce rules, policies, and procedures by monitoring the behavior of the receptor (subcontractor) and by rewarding performance. They can be defined as a task that aims to detect deviations. This task is performed by actors who are not part of the operating process at this point in time, but rather these actors take an external view of the exploitation process in order to have the most objective view possible when they check for the presence or absence of deviations detective controls take place during and after the task. A directory of verbs used to describe detective controls includes: to verify, to check, to execute, to effectuate, and to perform.

Table 1. Characteristics of L1 preventive controls and L2 detective controls

\begin{tabular}{|c|c|c|}
\hline & $\begin{array}{l}\text { Preventive } \\
\text { Control }\end{array}$ & $\begin{array}{l}\text { Detective } \\
\text { Control }\end{array}$ \\
\hline Aim: & $\begin{array}{l}\text { Performance of } \\
\text { the operating } \\
\text { process }\end{array}$ & Detect deviations \\
\hline Task: & $\begin{array}{l}\text { May not result in } \\
\text { action directly } \\
\text { influencing the } \\
\text { process }\end{array}$ & $\begin{array}{l}\text { Performed by } \\
\text { actors not part of } \\
\text { the operating } \\
\text { process }\end{array}$ \\
\hline Actors: & $\begin{array}{l}\text { Internal view } \\
\text { (part of the } \\
\text { process) } \\
\text { Entrusted with } \\
\text { responsibilities }\end{array}$ & $\begin{array}{l}\text { External view } \\
\text { (objective) when } \\
\text { checking for } \\
\text { deviations }\end{array}$ \\
\hline Temporality: & $\begin{array}{l}\text { Prior to \& during } \\
\text { task }\end{array}$ & $\begin{array}{l}\text { During \& after } \\
\text { task }\end{array}$ \\
\hline
\end{tabular}

\subsection{The temporal aspect of averting an event}

Events frequently occur either during or after the completion of an activity, as a result of the dysfunction that took place during the activity. Therefore, the most effective time to control and avoid potential events is either prior to the task (L1 preventive control) or during the task ( $L 1$ preventive control and/or L2 detective control). In contrast, a control that is carried out after the task such as an L2 detective control serves to verify results but is futile to prevent potential events given that such controls often take place after the event, therefore are unable to detect and correct the actions that set the event in motion. Nonetheless, once the event is in motion, such L2 detective controls are effective in detecting the event (see figure 2 below).

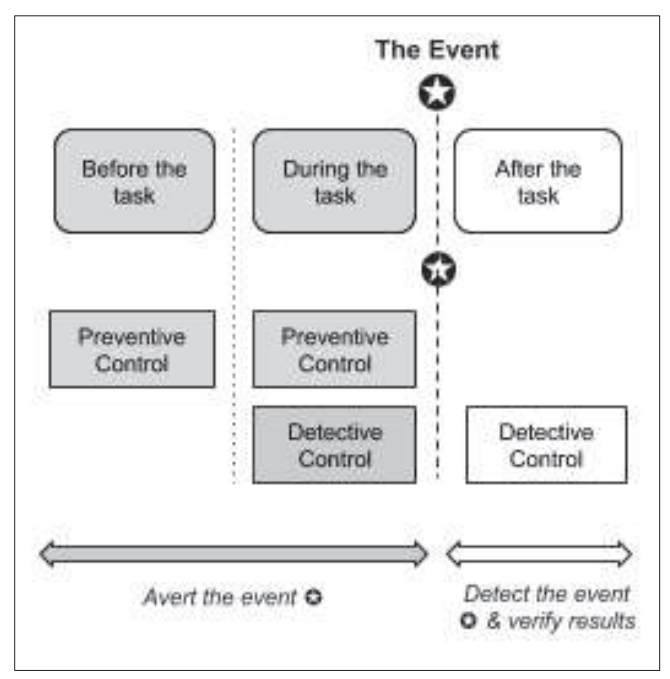

Fig. 2. The temporal aspect of management controls used in the prevention of an event

The temporal aspect of risk management and the additional parameters of $L 1$ preventive and L2 detective controls, detailed above, are the nucleus of this AA model. Specifically, L1 preventive and $L 2$ detective controls act from an antagonistic point of view (crossed actions in opposite directions) with regards to when the controls take place (before/after the activity) and with regards to the actor's position (internal and part of the operating process/ external and not part of the operating process). These managerial controls also act from an agonistic point of view (parallel actions in the same direction) with regards to the common regulator (contractor) and receptor of the forces (subcontractor) as well as their joint aim in safety management of decreasing risks, events.

When analyzing risk management using AAS, it is possible to extrapolate many of the characteristics presented in section 2.3 and apply them to management controls. The first characteristic allows us to identify preventive and detective control as an AA couple. The second reinforces our intuition that risk management is a dissipative system (not static) with a set of oscillating equilibrium constants (ideal balances between preventive and detection control). The third can also be applied to risk management, which consists of a network of management controls whose actions on one couple (by way of preventive and detective 
controls) may rebalance the network thus preventing potential events. The fourth highlights the heterogeneity and constituent division of the preventive-detective control dynamics. On one hand, preventive controls act in their own interest (as an independent barrier) to avert potential events and focus on an internal view of the operating task, while simultaneously providing a protection layer to compensate for human and organizational failures. On the other hand, detective controls offer their own independent external and objective view of the operating process and come into force at the failure of prevention controls, while concurrently working in unison as a protection system to maintain safe operations should an event occur. The fifth integrates dichotomies present in risk management via incompatible elements such as subcontractors who may act in their own interest (the basis of non-cooperation in relational risk); while concurrently conforming to converging safety objectives (preventive social control). Similarly, the co-operation between subcontracting firms when one firm trains another while at the same time competing for knowledge acquisition and performance. The sixth highlights the pathological homeostasis or autonomic state of risk management, which yields alternative strategies such as multi-layered safety barriers that, may seem incompatible with traditional business practices that focus on benefit-cost ratios. The seventh emphasizes false ago-antagonists couples, which are not prevalent in risk management. The final characteristic describes the need to identify the meta-model of risk management. This model would offer a tool to analyze both unwanted (conceived) situations as well as unimagined events. Therefore, after careful study of the eight characteristics of AAS, risk management through $L 1$ preventive and $L 2$ detective controls is a type of AAS.

\section{Preventive and Detective Controls: An Ago- antagonistic System - Empirical references of Ago-antagonistic Couples at the CEA}

For any single task, multiple types of control can be used depending on the type of risk one aims to mitigate. Certain tasks such as those surrounding Safety \& Occupational Safety require both actions of prevention \& of detection. The following provides several empirical references of the use of $L 1$ preventive and L2 detective controls at two CEA nuclear facilities:

\subsection{Example 1}

In order to ensure Health and Occupational Safety (H\&OS) objectives are being met, the CEA carries out three controls: A safety brief called "Safety Minute" to prevent potential relational risk and compliance and regulation risks that is used before the task ( $L 1$ preventive control); A safety inspection (L2 detective controls) to verify the application of H\&OS procedures during the task; and once again reapplies a $L 1$ preventive control in the form of a "Safety Minute", until the next task; thereby, reinforcing the $L 1$ preventive controls at the beginning and at the end of each task.

\subsection{Example 2}

According to the literature (Anderson et al., 2014; Eisenhardt, 1985; Hopwood, 1976; Merchant, 1985; Ouchi, 1979) results are often controlled after the task using L2 detective controls to "ensure the subcontractor obtains results that comply with their commitments" (Moreno Alarcon et al., 2019; 2020), thereby mitigating performance risk and compliance and regulatory risks. However, the CEA prefers to mitigate such risks by using also an $L 1$ preventive control during the task to "ensure the procedures are performed according to the predetermined specifications" (Moreno Alarcon et al., 2019; 2020). These examples indicate a transition in the ratio of controls used, moving towards a new balance of risk prevention by augmenting Level 1 controls.

\subsection{Example 3}

The co-activity meeting is a type of L1 preventive control that takes place before any activity, to discuss the day's tasks, elements of concern, previous experiences and points to consider while performing these tasks. Additionally, prior to each (high-risk) activity, operational preparation occurs in the form of a detailed pre-job briefing meeting, an $L 1$ preventive control that details the order of procedures to be performed and the presence of "stop points". A stop point is a clearly 
designated "pause moment" during which the activity is halted, and the contractor (CEA) is called upon to verify the activity and to sign a document validating the task ( $L 2$ detective control); once authorized the subcontractor can continue with the activity. During the stop points, the contractor is not part of the initial operating process and therefore has an external objective view while inspecting the activity for the presence or absence of deviations.

At the end of this activity, a debrief of the subcontractors known as a "return on experience" is conducted to: determine if the results were obtained; discuss issues or concerns during the manoeuver (completion of the task, procedures and documents, equipment or tools, planning of the activity); determine points that were missed during the pre-job briefing; discuss future predicaments to avoid; and propose suggestions for this activity in the future. This debriefs serves as an 22 detective control from which the results will be taken into account the next time this activity is programmed. The information obtained from the return on experience will also be discussed during future L1 preventive controls such as future pre-job briefings and other operational preparations prior to the task. Specifically, this pre-job briefing discusses the intended results of the activity; the potential risks; the situations prone to errors; the alternative scenarios; and permits the appropriation of the previous returns on experience.

\section{Conclusion}

Risk management in the French Nuclear Industry can be described as a dynamic system with complex interactions between diverse subsystems including contractor - subcontractor; subcontracting risk-management tools, and preventive - detective controls amongst many others. Using systems thinking to model AA forces present in the risk management system, allows managers to identify and balance L1 preventive and $L 2$ detective controls used in risk management practices at the CEA. Therefore, it would be pertinent in future studies to comprehend the balancing mechanisms of the detection and prevention controls observed at the CEA. Such knowledge would be of service in designing an approach that incites managers to balance AA tensions between prevention and detective controls by learning to identify when agonistic-antagonistic unbalances have occurred.

After analyzing several empirical examples of current CEA practices, a hybrid multi-level control (Level 1 \& 2) synonymous with defence in depth strategy can be identified. The hybrid control that appears to be most efficient begins with an $L 1$ preventive control prior to the task, shadowed by an $L 1$ preventive or an L2 detective control during the task, and finally followed by a L1 preventive control that will take place between the end of this activity and the next time the same activity is carried out; thereby preventing future events.

In this way, preventive controls serve as both the alpha and the omega of risk prevention, thereby enforcing the classic safety approach that focuses on prevention of barriers and reducing the probability of event occurrence. Such procedures exist to prevent potential \& imaginable accidents but overlook inconceivable accidents. Therefore, the development of a template/tool or meta-model to compare accidents would allow a better understanding of accidents that occur either because the prevention barriers did not function (though the event was conceived) or because the prevention barriers did not exist (because the accident was unimagined and unexpected).

\section{References}

Anderson, S. W., Christ, M. H., Dekker, H. C., \& Sedatole, K. L. (2014). The Use of Management Controls to Mitigate Risk in Strategic Alliances: Field and Survey Evidence. Journal of Management Accounting Research, 26(1), 1-32.

Arnold, R. D., \& Wade, J. P. (2015). A Definition of Systems Thinking: A Systems Approach. Procedia Computer Science, 44, 669-678.

Arrêté du 7 février, 2012. Arrêté du 7 février 2012 fixant les règles générales relatives aux installations nucléaires de base.

Bernard-Weil, E. (1992). Agonistic Antagonistic Systemics: An Introduction To Bilateral and Paradoxically Unilateral - Strategies. Kybernetes, 21(4), 47-66.

Bernard-Weil, E. (1999). La théorie des systèmes ago-antagonistes. Le Débat, 106(4), 106.

Bernard-Weil, E. (2002). Approche des systèmes ago-antagonistes. Techniques de l'ingénieur. 
L'Entreprise Industrielle, (AG1575), AG15751.

Bernard-Weil, E. (2003). Ago-antagonistic systems. In Quantum mechanics, mathematics, cognition and action (pp. 325-348). Springer.

Bernard-Weil, E. (2003). Theorie et Praxis des Systems Ago-antagonistes, 11.

Bernard-Weil, E., Duvelleroy, M., \& Droulez, J. (1975). Analogical study of a model for the regulation of ago-antagonistic couples. Application to adrenal-postpituitary interrelationships. Mathematical Biosciences, 27(3-4), 333-348.

Corbel, P., Denis, J.-P., \& Payaud, M. A. (2007). Ago-antagonisme

positivisme/constructivisme: quelques formes de travail épistémique.

Corbel, P., \& Terziovski, M. (2008). Organizational excellence, knowledge and the theory of the firm: To what extent can we build on the Knowledge-Based View of the firm? THE THEORIES AND PRACTICES OF ORGANIZATION EXCELLENCE: NEW PERSPECTIVES, 177.

Das, T. K., \& Teng, B.-S. (2000). A ResourceBased Theory of Strategic Alliances. Journal of Management, 26(1), 31-61.

Das, T. K., \& Teng, B.-S. (2001). Trust, Control, and Risk in Strategic Alliances: An Integrated Framework. Organization Studies, 22(2), 251283.

De Rosnay, J. (1975). Le macrocosme: vers une vision globale. Éditions du Seuil.

De Rosnay, J. (2014). Le macroscope. Vers une vision globale. Le seuil.

Donnadieu, G., \& Karsky, M. (2002). Systemic: Think and act in complexity. Liaisons.

Durand, D. (2006). La systémique (10e éd.). Paris: Presses Universitaires de France (PUF).

Eisenhardt, K. M. (1985). Control: Organizational and Economic Approaches. Management Science, 31(2), 134-149.

Garbolino, E., Chéry, J.-P., \& Guarnieri, F. (2019). The Systemic Approach: Concepts, Method and Tools. In F. Guarnieri \& E. Garbolino (Eds.), Safety Dynamics: Evaluating Risk in Complex Industrial Systems (pp. 1-30). Cham: Springer International Publishing.

Goh, Y. M., Brown, H., \& Spickett, J. (2010). Applying systems thinking concepts in the analysis of major incidents and safety culture. Safety Science, 48(3), 302-309.

Hopwood, A. G. (1976). Accounting and human behavior. Prentice Hall.
INSAG. (1996). Defence in depth in nuclear safety (Safety Reports No. INSAG-10) (p. 33). Vienna: International Atomic Energy Agency.

INSAG. (1999). Basic safety principles for nuclear power plants: a report by the International Nuclear Safety Advisory Group (75thINSAG-3 Rev. 1 ed.). Vienna: International Atomic Energy Agency.

Martinet, A. C., \& Payaud, M. A. (2006). Absorption d'incertitude, enrichissement des stratégies et cadres intermédiaires: une modélisation ago-antagoniste. Management International Montréal, 10(2), 29-14.

Merchant, K. A. (1985). Control in business organization. Financial Times/Prentice Hall.

Moreno Alarcon, D. P., Vautier, J.-F., Hernandez, G., \& Guarnieri, F. (2019, July). Applying Safety Leadership and Systems Thinking to the Formal and Informal Controls Approach Used in Safety and Risk Management Within the French Nuclear Sector. In International Conference on Applied Human Factors and Ergonomics (pp. 481-492). Springer, Cham.

Moreno Alarcon D.P., Vautier J.F., Hernandez G., Guarnieri F. (2020) Applying Safety Leadership and Systems Thinking to the Formal and Informal Controls Approach Used in Safety and Risk Management Within the French Nuclear Sector. In: Kantola J., Nazir S. (eds) Advances in Human Factors, Business Management and Leadership. AHFE 2019. Advances in Intelligent Systems and Computing, vol 961. Springer, Cham

Nunez, E. (1997). What are ago-antagonistic couples? Their role in normal and pathological situations. Therapeutical consequences. Psychoneuroendocrinology, 22, S95-S101.

Ouchi, W. G. (1979). A conceptual framework for the design of organizational control mechanisms. In C. Emmanuel, D. Otley, \& K. Merchant (Eds.), Readings in Accounting for Management Control (pp. 63-82). Springer US.

Tosello, M., Lévêque, F., Dutillieu, S., Hernandez, G., \& Vautier, J.-F. (2012). Conditions for the successful integration of Human and Organizational Factors (HOF) in the nuclear safety analysis. Work, 41(Supplement 1), 2656-2660.

Vautier, J.-F., Dechy, N., Coye de Brunélis, T., Hernandez, G., Launay, R., \& Moreno Alarcon, D. P. (2018a). Benefits of systems thinking for a human and organizational factors approach to safety management. Environment Systems and Decisions, 38(3), 353-366. 
Vautier, J.-F., Hernandez, G., Sylvestre, C., Barnabé, I., Dutillieu, S., Tosello, M., Moreno Alarcon, D. P. (2018b). Averting Inadequate Formulations During Cause Analysis of Unwanted Events. In S. Bagnara, R. Tartaglia, S. Albolino, T. Alexander, \& Y. Fujita (Eds.), Proceedings of the 20th Congress of the
International Ergonomics Association (IEA 2018) (pp. 607-612). Springer International Publishing.

Zouaghi, I., \& Spalanzani, A. (2009). Supply chains: ago-antagonistic systems through coopetition game theory lens, 12 . 